| Puji Lestari

\title{
ANALISIS PERUBAHAN SOSIAL PADA MASYARAKAT SAMIN \\ (Studi Kasus di Desa Mendenrejo, Kecamatan Kradenan, Blora)
}

\author{
Puji Lestari ${ }^{1}$
}

\begin{abstract}
Abstrak
Penelitian yang berjudul "Analisis Perubahan Sosial Pada Masyarakat Samin : Studi Kasus di Desa Mendenrejo, Kecamatan Kradenan, Blora) ", ini bertujuan untuk mengetahui faktor-faktor yang menyebabkan perubahan sosial pada masyarakat Samin, bentuk-bentuk perubahan yang terjadi pada masyarakat Samin, dan dampak perubahan sosial pada masyarakat Samin.

Metode yang digunakan dalam penelitian ini adalah metode kualitatif yang menekankan pada aspek kedalaman informasi yang diperoleh melalui wawancara, didukung pula oleh observasi dan dokumentasi di lapangan. Adapun sampel yang diambil adalah para perangkat desa Mendenrejo dan warga desa Mendenrejo.

Hasil penelitian menunjukkan bahwa perubahan pada masyarakat Samin bisa dilihat dari aspek fisik maupun non fisik. Secara fisik, bangunan rumah masyarakat Samin sudah menyerupai rumah masyarakat lainnya. Begitu pula dengan kemajuan teknologi juga sudah banyak yang menggunakan mekanisasi pertanian. Sebagian masyarakat sudah ada pula yang bisa dicermati, diantaranya adalah mengenai pendidikan. Sebagian masyarakat Samin sudah ada yang mengenyam pendidikan formal, bahkan ada pula yang sudah lulus menjadi sarjana dan mengabdikan diri untuk membangun desanya. Ada pula perubahan dari sisi ketertiban administrasi sebagai penduduk, masyarakat Samin memiliki KTP yang di dalamnya memuat agama mereka yaitu agama Islam. Meskipun pada prakteknya sebagian masyarakat Samin masih memegang teguh ajaran agama Adam, namun ada pula yang sudah memeluk agama Islam dan menjalankan ibadah sesuai dengan syari'at Islam.
\end{abstract}

Kata kunci : perubahan sosial, masyarakat, samin

\footnotetext{
${ }^{1}$ Penulis adalah pengajar pada prodi Pendidikan Sosiologi FISE UNY
} 


\section{A. Pendahuluan}

Pembangunan manusia yang dicanangkan sebagai titik sentral pembangunan nasional bukanlah semata-mata untuk mensukseskan pembangunan tetapi justru pembangunan itu sendiri harus ditujukan untuk manusia. Oleh karena sumber daya manusia bukan hanya sarana untuk memikul beban pembangunan, tetapi harus merupakan sasaran utama dari pembangunan. Ini berarti kesempatan kerja yang berhasil diciptakan oleh pembangunan merupakan salah satu tolok ukur dalam menilai keberhasilan pembangunan.

Pembangunan merupakan bentuk perubahan sosial yang terarah dan terncana melalui berbagai macam kebijakan yang bertujuan untuk meningkatkan taraf kehidupan masyarakat. (http://learning-of slametwidodo.corn/). Pembangunan yang dilakukan sebenarnya merupakan suatu proses perubahan pada berbagai aspek kehidupan. Perubahan tersebut tidak hanya berupa perubahan fisik saja namun banyak juga yang bersifat non fisik.

Masyarakat Samin yang memiliki berbagai tradisi dan budaya bisa dikategorikan sebagai salah satu kelompok etnik yang ada di Indonesia. Sementara itu Pemerintah Propinsi Jawa Tengah juga mengakui masyarakat Samin ini sebagai salah satu kelompok etnik yang ada di Jawa Tengah dari empat etnik yang ada. Komunitas Samin ialah sekelompok orang yang mengikuti ajaran Samin Surosentiko yang muncul pada masa kolonial Belanda. (http://learning-of slametwidodo.com/).

Samin Surosentiko di usianya yang 31 tahun pada tahun 1890 mulai menyebarkan ajarannya kepada orangorang sedesanya. Ajarannya mendapat tanggapan baik, dan segera memikat orang banyak dari desa-desa sekitarnya. Semula ajaran itu tidak serta merta menarik minat pemerintah dan tidak juga menimbulkan persoalan bagi pemerintahan kolonial. Namun sekitar tahun 1905 terjadi perubahan, karena para pengikut Samin mulai menarik diri dari kehidupan umum di desanya, menolak memberikan sumbangan pada lumbung desa dan menggembalakan ternaknya bersama ternak yang lain. (Widiyanto, 1983 ). Sehingga pada waktu itu masyarakat Samin dapat diidentifikasikan sebagai masyarakat yang ingin membebaskan dirinya dari ikatan tradisi besar yang dikuasai oleh elit penguasa yaitu pemerintahan kolonial.

Sebagai salah satu kelompok etnik yang ada di Indonesia, masyarakat Samin memiliki nilai-nilai budaya yang berbeda dengan masyarakat lainnya. Selama lebih dari 100 tahun masyarakat Samin sudah mengalami perubahan pada pranata sosial dan kebudayaan yang selama ini mereka anut. Bisa dikatakan bahwa Tradisi Saminisme sekarang sudah berubah, artinya Saminisme sudah bukan lagi menjadi kebanggaan dalam struktur sosial dimana mereka hidup. Apabila ditinjau dari sistem nilai, Saminisme sudah tidak lagi menjadi aturan dalam pluralitas nilai yang berada di tengah-tengah mereka. (http://learning-of

slametwidodo.com/)

Perubahan yang terjadi pada masyarakat Samin tentu saja tidak terlepas dari derasnya arus modernisasi. Modernisasi dalam lingkup masyarakat tradisional akan menimbulkan implikasi terhadap masyarakat tersebut. Sebagian besar masyarakat tradisional masih menjunjung tinggi nilai-nilai yang diwarisi secara turun temurun dari nenek moyangnya dulu. Tidaklah mengherankan kelompok masyarakat seperti ini telah memiliki pola budaya tertentu. Di sisi lain adanya modernisasi tentu akan membawa pola budaya baru bagi masyarakat tersebut 
yang mungkin berbeda dengan norma serta nilai yang lama. (http:/ / learningof.slametwidodo.com/).

Nilai-nilai baru yang masuk seiring dengan derasnya arus modernisasi membawa konsekuensi perubahan pada masyarakat Samin di berbagai bidang. Oleh karena itu dalam penelitian ini akan memfokuskan kajian pada analisis perubahan sosial pada masyarakat Samin.

\section{B. Kajian Pustaka}

1. Perubahan social

a. William F Ogburn

Ruang lingkup perubahanperubahan sosial meliputi unsur-unsur kebudayaan baik yang material maupun yang immaterial, yang ditekankan adalah pengaruh besar unsur-unsur kebudayaan materiil terhadap unsur-unsur immaterial. (Soekanto, 1999).

b. Mac Iver

Memfokuskan pada adanya pembedaan antara utilitarian elements dengan cultural elements yang dilandaskan pada kepentingankepentingan manusia baik primer maupun sekunder. Utilitarian elements disebut dengan civilization. Yang dimaksud adalah segala mekanisme dan organisasi yang dibuat manusia untuk dapat memenuhi semua kebutuhan hidupnya, didalamnya termasuk dalam menguasai kondisikondisi kehidupannya, termasuk di dalamnya sistem-sistem organisasi sosial, teknik dan alat-alat material. Pesawat telepon, jalan kereta api, sekolah, hukum dan seterusnya dimasukkan ke dalam golongan tersebut. Sedangkan, culture adalah ekspresi jiwa yang terwujud dalam cara-cara hidup dan berpikir, pergaulan hidup, seni kesusastraan, agama, rekreasi dan hiburan. Sebuah potret, novel, drama, film, permainan, filsafat dan sebagainya termasuk culture, karena hal-hal tersebut secara langsung memenuhi kebutuhan manusia.

c. Gillin dan Gillin

Perubahan-perubahan sosial sebagai suatu variasi dan cara-cara hidup yang telah diterima, baik karena perubahan-perubahan kondisi geografis, kebudayaan material, komposisi penduduk, ideologi maupun karena adanya difusi ataupun penemuan-penemuan baru dalam masyarakat.

\section{d. Samuel Koenig}

Perubahan sosial menunjuk pada modifikasi-modifikasi yang terjadi dalam pola-pola kehidupan manusia. Modifikasi-modifikasi mana terjadi karena sebab-sebab intern maupun sebab-sebab ekstern.

e. Selo Soemarjan

Perubahan sosial sebagai perubahan-perubahan pada lembagalembaga kemasyarakatan di dalam suatu masyarakat yang mempengaruhi sistem sosialnya, termasuk di dalamnya nilai-nilai, sikap dan pola perilaku di antara kelompok-kelompok dalam masyarakat. Penekanan defmisi ini tertumpu pada lembaga-lembaga kemasyarakatan sebagai himpunan pokok manusia, dimana perubahan yang terjadi akan mempengaruhi segisegi struktur masyarakat lainnya.

f. Kingsley Davis

Perubahan sosial sebagai perubahan-perubahan yang terjadi dalam struktur dan fungsi masyarakat.

2. Masyarakat Samin Masyarakat Samin adalah keturunan para pengikut Samin Soerontiko yang mengajarkan sedulur sikep, dimana dia mengobarkan semangat perlawanan terhadap Belanda dalam bentuk lain di luar kekerasan. Sedulur Sikep hidup secara tersebar di pantai utara Jawa Tengah, seperti Kudus, Pati, Blora, Rembang, Bojonegoro bahkan sampai ke Ngawi.

Samin Soerontiko sering disebut juga sebagai Raden Kohar. Ia masih 
berdarah bangsawan Majapahit yang hidup pada zaman kolonial Belanda. Karena alasan tertentu memutuskan meninggalkan gemerlap dunia kebangsawanan. Ia mendalami keilmuan spiritual yang saat itu sudah mulai diintervensi oleh kepentingan kelompok tertentu, khususnya oleh agama-agama baru dan tata kehidupan kolonial. Mbah Samin mendalami sendiri nilai-nilai budi luhur serta beladiri menentang penjajahan Belanda dan pada akhirnya mengajarkan kepada murid-muridnya. Begitu mencoloknya sikap Mbah Samin terhadap tata kehidupan saat itu, sehingga sampai kini orang lain mengatakan " Dasar orang Samin" pada tindak-tanduk serupa. (Wahono $\mathrm{dkk}, 2002)$.

Bentuk yang dilakukan adalah menolak membayar pajak, menolak segala peraturan yang dibuat pemerintah kolonial. Masyarakat ini acap memusingkan pemerintah Belanda maupun penjajahan Jepang karena sikap itu, sikap yang hingga sekarang dianggap menjengkelkan oleh kelompok diluarnya. Masyarakat Samin sendiri juga mengisolasi diri sehingga baru pada tahun 70an mereka baru tahu Indonesia telah merdeka. (http://rinangxu.wordpress.com/2006 112/07/samin anarchy-rebelbudaya/).

Orang luar Samin sering menganggap mereka sebagai kelompok yang lugu, suka mencuri, menolak membayar pajak, dan acap menjadi bahan lelucon terutama di kalangan masyarakat Bojonegoro. Pokok ajaran Samin diantaranya adalah :

- Agama adalah senjata atau pegangan hidup. Paham Samin tidak membeda $\neg$-bedakan agama, yang penting adalah tabiat dalam hidupnya.

- Jangan mengganggu orang, jangan bertengkar, jangan irihati dan jangan suka mengambil milik orang lain.

- Bersikap sabar dan jangan sombong.

- Manusia harus memahami kehidupannya, sebab roh hanya satu dan dibawa abadi selamanya.

- Bila orang berbicara, harus bisa menjaga mulut, jujur dan saling menghormati. Orang Samin dilarang berdagang karena terdapat unsur 'ketidakjujuran' didalamnya. Juga tidak boleh menerima sumbangan dalam bentuk apapun.

Masyarakat Samin terkesan lugu, bahkan lugu yang amat sangat, berbicara apa adanya, dan tidak mengenal batas halus kasar dalam berbahasa karena bagi mereka tindaktanduk orang jauh lebih penting daripada halusnya tutur kata. Kelompok ini terbagi dua, yakni Jomblo-ito atau Samin Lugu, dan Samin Sangkak, yang mempunyai sikap melawan dan pemberani. Kelompok ini mudah curiga pada pendatang dan suka membantah dengan cara yang tidak masuk akal. Ini yang sering menjadi stereotip dikalangan masyarakat Bojonegoro dan Blora. Mereka melaksanakan pernikahan secara langsung, tanpa melibatkan lembaga-lembaga pemerintah bahkan agama, karena agama mereka tidak diakui negara. Mereka menganggap agamanya sebagai Agama Adam, yang diterapkan turun temurun. Dalam buku Rich Forests, Poor People Resource Control and Resistance in Java, Nancy Lee Peluso menjelaskan para pemimpin Samin adalah guru tanpa buku, pengikut-pengikutnya tidak dapat membaca ataupun menulis. Suripan Sadi Hutomo dalam Tradisi dan Blora (1996) menunjuk dua tempat penting dalam pergerakan Samin: Desa Klopodhuwur di Blora sebelah selatan sebagai tempat 
bersemayam Samin Surosentiko, dan Desa Tapelan di Kecamatan Ngraho, Bojonegoro, yang memiliki jumlah terbanyak pengikut Samin. Mengutip karya Harry J. Benda dan Lance Castles (1960), Suripan menyebutkan, orang Samin di Tapelan memeluk saminisme sejak tahun 1890. Dalam Encyclopaedie van Nederlandsch Indie (1919) diterangkan, orang Samin seluruhnya berjumlah 2.300 orang (menurut Darmo Subekti dalam makalah Tradisi Lisan Pergerakan Samin, Legitimasi Arus Bawah Menentang Penjajah, 1999, jumlahnya 2.305 keluarga sampai tahun 1917, tersebar di Blora, Bojonegoro, Pati, Rembang, Kudus, Madiun, Sragen, dan Grobogan) dan yang terbanyak di Tapelan.

(http:// rinangxu.wordpress.com/2006 /12/07/samin-anarchy $\neg$ rebelbudaya/).

Sebagai gerakan yang cukup besar saminisme tumbuh sebagai perjuangan melawan kesewenangan Belanda yang merampas tanah-tanah dan digunakan untuk perluasan hutan jati pada zaman penjajahan di Indonesia. Sekitar tahun 1900, mandor hutan yang menjadi antek Belanda mulai menerapkan pembatasan bagi masyarakat dalam soal pemanfaatan hutan. Para mandor itu berbicara soal hukum, peraturan, serta hukuman bagi yang melanggar. Tapi para saminis, atau pengikut Samin, menganggap remeh perkara itu. Sosialisasi hukum itu lantas ditindaklanjuti pemerintah Belanda dengan pemungutan pajak untuk air, tanah, dan usaha ternak mereka. Pengambilan kayu dan hutan harus seizin mandor polisi hutan. Pemerintah Belanda berdalih semua pajak kelak dipakai untuk meningkatkan kesejahteraan rakyat. Akal bulus itu ditentang oleh masyarakat pinggir hutan di bawah komando. Samin Surosentiko yang diangkat oleh pengikutnya sebagai pemimpin informal tanpa persetujuan dirinya. Oleh para pengikutnya Samin Surosentiko dianggap sebagai Ratu Tanah Jawi atau Ratu Adil Heru Cakra dengan gelar Prabu Panembahan Suryangalam. Para pengikut Samin berpendapat, langkah swastanisasi kehutanan tahun 1875 yang mengambil alih tanah-tanah kerajaan menyengsarakan masyarakat dan membuat mereka terusir dan tanah leluhurnya.

Sebelumnya, pemahaman pengikut Samin adalah: tanah dan udara adalah hak milik komunal yang merupakan perwujudan kekuasaan Tuhan Yang Maha Esa. Mereka menolak berbicara dengan mandormandor hutan dan para pengelola dengan bahasa krama. Sebagai gantinya para saminis memperjuangkan hak-haknya dalam satu bingkai, menggunakan bahasa yang sama, Jawa ngoko yang kasar alias tidak taklim. Sasaran mereka sangat jelas, para mandor hutan dan pejabat pemerintah Belanda. Ketika mandor hutan menarik pajak tanah, secara demonstratif mereka berbaring di tengah tanah pekarangannya sambil berteriak keras, "Kanggo!" (punya saya). Ini membuat para penguasa dan orang-orang kota menjadi sinis dan mengkonotasikan pergerakan tersebut sebagai sekadar perkumpulan orang tidak santun. Penguasa bahkan mendramatisasikan dengan falsafah Jawa kuno yang menyatakan "Wong ora bisa basa" atau dianggap tak beradab. Akibatnya, para pengikut Samin yang kemudian disebut orang Samin, dicemooh dan dikucilkan dari pergaulan. Ketika pergerakan itu memanas dan mulai menyebar di sekitar tahun 1905, pemerintah Belanda melakukan represi. Menangkap para pemimpin pergerakan Samin, juga mengasingkannya. Belanda juga mengambil alih tanah kepemilikan dari mereka yang tak mau membayar pajak. Namun tindakan pengasingan 
dan tuduhan gerakan subversif gagal menghentikan aktivitas para saminis. Sekarang pun sisa-sisa para pengikut Samin masih ditemukan di kawasan Blora yang merupakan jantung hutan jati di P. Jawa. (http://rinangxu.wordpress.com/2006 L12/07/samin-anarchy-rebelbudaya $/)$.

\section{Metode Penelitian}

1. Penentuan Satuan Kajian Pendekatan penelitian merupakan keseluruhan cara atau kegiatan yang dilakukan dalam melaksanakan penelitian mulai dari perumusan masalah sampai dengan penarikan kesimpulan. Dalam penelitian ini digunakan pendekatan kualitatif dengan mengambil studi kasus.

Untuk mengetahui lingkup dari subyek penelitian sebagai sumber, tempat memperoleh keterangan (fakta), maka dalam penelitian kualitatif digunakan penentuan satuan kajian (Moleong, 1989 : 165). Teknik sampling dalam penelitian kualitatif berbeda dengan yang non kualitatif, karena menggunakan metode kualitatif maka sampel yang diambil tidak ditentukan jumlahnya. Maksud sampling dalam hal ini ialah menjaring sebanyak mungkin informasi dari berbagai macam sumber dan bangunannya. Sampling bertujuan untuk menggali informasi yang akan menjadi dasar dan rancangan dan teori yang muncul. Sampel dalam penelitian kualitatif tidak dilakukan secara acak akan tetapi dengan menggunakan sampel bertujuan (purposive sample) yang mempunyai ciri-ciri sebagai berikut :

a. Rancangan sampel yang muncul, sampel tidak dapat ditentukan atau ditarik terlebih dahulu.

b. Pemilihan sampel secara berurutan dengan tujuan untuk memperoleh variasi sebanyakbanyaknya.

c. Penyesuaian berkelanjutan dan sampel sehingga pemilihan sampel berdasarkan pada fokus penelitian.

d. Pemilihan berakhir jika sudah terjadi pengulangan.

Purposive sample ini dipilih karena populasi yang akan diambil tidak bersifat homogen. Sedangkan unit analisis dalam penelitian ini adalah warga yang tinggal di desa Mendenrejo. Berdasarkan pertimbangan-pertimbangan yang ada penulis mengambil sampel sebagai berikut :

a. Perangkat desa Mendenrejo

b. Warga desa Mendenrejo

2. Lokasi Penelitian

Penelitian dilakukan di desa Mendenrejo, kecamatan Kradenan, kabupaten Blora, Jawa Tengah.

3. Langkah-langkah Penelitian

a. Tahap Pra Lapangan

Pada tahap ini peneliti mengadakan survei pendahuluan. Selama proses ini peneliti mengadakan penjajakan lapangan terhadap lokasi penelitian, studi literatur serta menyusun rancangan penelitian

b. Tahap Pekerjaan Lapangan

Dalam tahap ini peneliti memasuki dan memahami lokasi penelitian dalam rangka pengumpulan data

c. Tahap Analisis Data

Peneliti melakukan serangkaian proses analisa data kualitatif sampai pada interpretasi data-data yang diperoleh sebelumnya. Selain itu peneliti juga menempuh proses triangulasi data yang dikomparasikan dengan teori kepustakaan.

d. Tahap Evaluasi dan Pelaporan

Tahap ini merupakan tahap terakhir dan dilaksanakan setelah penelitian diuji.

4. Teknik Pengumpulan Data 
Teknik pengumpulan data adalah cara-cara untuk memperoleh data yang lengkap, objektif dan dapat dipertanggungjawabkan

kebenarannya serta sesuai dengan tujuan penelitian. Menurut Lofland and Lofland (1984 : 47) dalam Moleong (1989 : 112) sumber data utama dalam penelitian kualitatif ialah kata-kata dan tindakan selebihnya adalah data tambahan seperti dokumen dan lain-lain. Sedangkan Hadawi Nawawi (1983) mengemukakan bahwa data penelitian dapat diklasifikasikan sebagai berikut :

a. Data Primer

Yaitu data autentik atau data langsung dan tangan pertama tentang masalah yang diungkapkan. Data ini disebut juga dengan data ash.

b. Data Sekunder

Yaitu data yang mengutip dan sumber lain sehingga bersifat tidak autentik karena sudah diperoleh dan tangan kedua, dengan demikian data ini disebut juga data tidak ash.

Untuk mengumpulkan data yang diperlukan dalam penelitian ini digunakan beberapa teknik pengumpulan data, yaitu :

a. Wawancara mendalarn

Wawancara dilakukan dengan menyiapkan terlebih dahulu daftar pertanyaan. Namun dalam prakteknya daftar pertanyaan ini tidak mengikat jalannya wawancara.

b. Observasi

Observasi dilakukan di kampung Jlagran untuk mengetahui secara langsung bagaimana para orang tua mengasuh anak-anak mereka.

c. Dokumentasi

Data-data pendukung lain diperoleh melalui dokumendokumen penting seperti dokumen lembaga yang diteliti termasuk di dalamnya data administrasi lembaga. Di samping itu foto maupun sumber tertulis lain yang mendukung juga bisa digunakan dalam proses dokumentasi.

5. Instrumen Penelitian

Instrumen utama adalah peneliti sendiri karena pendekatan yang digunakan adalah kualitatif. Sehingga kedudukan peneliti sekaligus perencana, pelaksana, pengumpul data, penafsir data dan pelapor hasil penelitian. Di samping itu dapat juga digunakan instrumen lain seperti alat tulis, pedoman wawancara, pedoman observasi dan dokumentasi.

6. Analisis Data

Teknik analisis data menggunakan langkah-langkah seperti yang dijelaskan oleh Miles dan Huberman (1992) yaitu :

a. Reduksi Data

Proses ini dilakukan dengan mengklasifikasikan data-data dari catatan tertulis di lapangan

b. Penyajian Data

Data yang telah direduksi disajikan dalam laporan yang sistematis, mudah dibaca dan dipahami baik secara keseluruhan maupun bagian-bagian.

c. Pengambilan Kesimpulan

Data yang telah diproses kemudian ditarik kesimpulan dengan menggunakan metode induktif yakni proses penyimpulan dari hal-hal yang sifatnya khusus ke hal-hal yang sifatnya umum agar diperoleh kesimpulan yang obyektif.

7. UP Keabsahan Data

Peneliti dalam memeriksa keabsahan data menggunakan teknik:

a. Triangulasi data yaitu teknik pemeriksaan data yang memanfaatkan sesuatu yang lain di luar data tersebut untuk keperluan pengecekan atau sebagai pembanding data tersebut. Triangulasi dibedakan menjadi empat macam yaitu dengan sumber, metode, penyidik dan teori (Moleong, 2000). Sedangkan teknik yang 
digunakan oleh peneliti adalah triangulasi dengan sumber dan metode.

b. Membercheck yaitu mengulang garis besar apa yang diungkapkan oleh informan pada akhir wawancara guna mengoreksi bila ada kesalahan serta menambahkan apabila terdapat beberapa kekurangan.

\section{Hasil Penelitian dan Pembahasan}

Sebagaimana masyarakat pada umumnya, masyarakat Samin juga memiliki norma kehidupan sehari-hari. Sebagai pegangan hidup dalam berperilaku sehari-hari, setidaknya ada beberapa norma yang bisa dicermati pada masyarakat Samin, yaitu :

\section{Norma agama}

Konsep masyarakat Samin mengenai agama berbeda dengan konsep agama yang diberikan oleh para antropolog dan sosiolog. Dimana kata "agama" bisa dikaitkan dengan sesuatu yang sifatnya supra, berporos pada kekuatan-kekuatan non empiris (Hendropuspito dalam Heny P,1995). Menurut masyarakat Samin, "agama iku gaman" mengindikasikan bahwa masyarakat Sikep mempunyai kerangka acuan sendiri, bagaimana mereka memberi makna tentang hidup dan meletakkan nilai-nilai bersama. Konsep agama bagi masyarakat Sikep konsisten dengan bahasa Sikep, yaitu sebagai "gaman" satu sama lain. Untuk memahami konsep ini perlu diketahui bagaimana masyarakat Sikep memahami dunia ini.

Bila masyarakat ditanya mengenai agama mereka, pasti mereka akan menjawab bahwa agama mereka adalah agama adam dan kalimat lengkapnya " Agama iku gaman, gaman lanang. Adam pengucape. Dam, damele rabi. Menurut Heny $P$ (1995) hal ini bisa dijelaskan sebagai berikut:
Agama iku gaman : agama adalah senjata. Arti politisnya adalah untuk menolak masuknya unsur dari luar.

Gaman lanang: senjata laki-laki (arti seksual), alat kelamin laki-laki. Adam pengucape : "adam: alat untuk mengucapkan, berarti "adam" sama dengan bahasa. Bahwa seseorang yang akan melakukan hubungan persetubuhan dimulai dengan melakukan "jawab" pada waktu perkawinan. Sehingga bahasa berfungsi sebagai senjata.

Dam, damele rabi :"adam" (bahasa dan alat kelamin laki-laki digunakan sebagai alat untuk hubungan antar manusia, terutama antar laki-laki dan perempuan.

Dari penjelasan di atas, dapat disimpulkan bahwa "adam" mempunyai arti seksual dan kebahasaan, kedua arti tersebut saling melekat. Keduanya sama-sama berfungsi sebagai senjata, seperti yang ditunjukkan dalam "agama iku gaman"

Dalam hal ini masyarakat Samin sangat mementingkan aspek kejujuran yang dikaitkan dengan agama yang mereka miliki yaitu agama Adam. Masyarakat Samin hanya mengatakan apa yang mereka tahu dan mereka lakukan. Berkenaan dengan agama Adam ini, beberapa pokok ajaran yang terdapat didalamnya antara lain :
a. Tidak boleh bohong
b. Tidak boleh mencuri
c. Tidak boleh iri
d. Tidak boleh bertengkar

2. Norma kesopanan

Dalam hal kesopanan, pada masyarakat Samin bisa dilihat ketika mereka menjadi dengan ketika menerima tamu. Mereka akan menerima tamu dengan ramah dan bersahabat, sebab bagi masyarakat Sikep, tamu entah dari mana asalnya tetaplah dianggap sebagai sedulur (saudara).

3. Norma kebiasaan 
Kebiasaan masyarakat Samin ketika bertemu dengan orang lain adalah dengan menyapa satu sama lain. Apabila sapaan tidak dijawab maka orang yang menyapa akan segera mendatangi rumah orang yang disapa tersebut. Kebiasaan ini sudah berlangsung lama.

Lain lagi bila ada salah satu warga yang sedang mempunyai hajatan tertentu, maka dengan serta-merta seluruh warga akan bergotong royong membantu warga yang sedang mempunyai hajatan tersebut.

4. Norma tata kelakuan

$$
\text { Masyarakat Samin sangat }
$$
menjunjung tinggi kejujuran. Meskipun dulu pernah terdapat anggapan yang buruk mengenai komunitas Samin yaitu sebagai pemberontak. Hal ini terkait dengan kebijakan pemerintahan penjajah pada masa lalu. Ketidakpatuhan masyarakat Samin pada aturan membuat stigma yang buruk dilekatkan pada mereka.

5. Norma adat-istiadat

\section{a. Perkawinan}

Adat-istiadat masyarakat Samin tampak jelas pada sistem perkawinannya. Masyarakat Sikep menganut azas monogami dalam perkawinan, dan terekspresikan dalam ungkapan sisi kanggo salawase, yang artinya satu suami/istri untuk selamanya. Tujuan perkawinan adalah meneruskan keturunan dengan beranak-pinak (nurunke wiji sing sakbenere).

Konsep ideal mengenai perkawinan lebih ditekankan pada keinginan masing- $\neg$ masing pihak untuk kawin, dan perceraian terjadi bila salah satu dan pasangan suamiistri meninggal (cerai mati). Perkawinan yang diharapkan adalah perkawinan dengan orang-orang sepaham, tetapi tidak ada larangan untuk melakukan perkawinan dengan orang non sikep. Bagi masyarakat Sikep di Blora, dikenal konsep awu dan perkawinan yang diinginkan dan tidak diinginkan. Serta adanya larangan kawin bagi laki-laki yang lebih muda usianya dibanding perempuan yang akan dikawininya (Prasongko, 1981:84-88 dalam Heny P, 1995 : 60).

Perkawinan terjadi apabila seseorang laki-laki dan perempuan telah sama-`sama senang dan punya keinginan yang sama (dhemen lan karep) untuk membentuk rumah tangga. Dhemen dan karep ini sangat penting bagi pasangan yang akan kawin, meskipun pada kenyataannya sangat dikontrol oleh orangtuanya. Pada prinsipnya tidak ada paksaan dalam hal ini. Dhemen (senang) adalah keinginan memenuhi karep (maksud), dan karep sangat tergantung pada targeraknya hati. Peranan orang tua sangat besar dalam proses terjadinya perkawinan, meskipun selalu ditekankan bahwa anak bebas memilih.

Perkawinan menurut konsep masyarakat Sikep adalah bila telah terjadi hubungan persetubuhan antara seorang dan perempuan dalam masa nyuwita.

b. Tradisi

1. Tradisi pemeliharaan lingkungan

Tradisi yang berkaitan dengan pemeliharaan lingkungan hidup terutama adalah yang berkaitan dengan pemeliharaan lingkungan hidup terutama yang berkaitan dengan adanya sumur tua. Upacara yang terkait dengan sumur tua dan terkait dengan pertanian adalah nyadran sehabis panen, sebagai ungkap rasa syukur. (Titi Mumfangati dkk, 2007).

2. Tradisi dalam hubungan ketetanggaan

Bagi orang Samin, semua orang dianggap sebagai sedulur. Kadang- $\neg$ kadang pengertian sedulur tidak hanya sebagai pengakuan tetapi juga masih ada 
ikatan keluarga. Pengertian sedulur bagi mereka dapat juga dilekatkan pada orang yang baru saja dikenal. (Titi Mumfangati dkk, 2007).

3. Tradisi dalam hubungan kekerabatan

Pengertian kerabat

menunjukkan hubungan antara satu orang dengan orang lain berdasarkan pertalian darah. Pada masyarakat Samin, ada beberapa kerabat yang tinggal dalam satu dusun, ada pula yang berlainan dusun bahkan lain desa. Kepada kerabat yang lebih tua lebih dipentingkan untuk dalam berkunjung. (Titi Mumfangati dkk, 2007)

Pada suatu hajatan tertentu, biasanya warga Samin mengenakan pakaian adat yang biasa digunakan pada saat-saat ada pertemuan, ada tamu penting, atau pertemuan kekerabatan yang lain. Pakaian adat untuk para pria berupa baju hitam dengan potongan leher tegak dan mengenakan ikat kepala. Untuk wanita menggunakan baju kebaya dengan motif kembang-kembang dan kain jarik seperti wanita Jawa pada umumnya. (Titi Mumfangati, dkk, 2007)

Seiring dengan perkembangan jaman dan kemajuan pengetahuan yang ada, selalu ada perubahan yang menyertainya. Demikian pula yang terjadi pada masyarakat Samin, ada beberapa perubahan yang bisa dicermati yaitu :

1. Agama

Awalnya masyarakat Samin sangat memegang teguh ajaran agama Adam. Bahkan sampai sekarang pun masih menunjukkan hal yang sama. Hanya saja ketika peneliti menanyakan kepada Kepala Desa mengenai agama yang tertulis di KTP masing-masing warga Samin, maka jawaban yang didapat bukannya Agama Adam yang termuat di KTP. Namun dalam KTP jelas tertera agama Islam lah yang dianut. Tentu saja hal ini mengindikasikan sudah adanya perubahan status agama menurut aturan formal sesuai di KTP, sementara dalam prakteknya mereka tetap menerapkan agama Adam dalam kehidupan sehari-hari. Namun ada pula sekarang ini sebagian masyarakat Samin yang benar-benar memeluk agama Islam. Sarana peribadatan juga mendukung adanya perubahan ini, seperti dengan adanya Masjid dan Musholla di desa setempat.

2. Perkawinan

Dalam sistem perkawinan di masa lalu calon mempelai pria harus menginap terlebih dahulu di calon wanita, atau lebih sering dikenal dengan istilah nyuwita sampai beberapa bulan bahkan tahunan, namun sekarang sudah tidak dijalankan lagi karena dianggap bertentangan dengan ajaran agama Islam. Mengingat sekarang ini sebagian masyarakat Samin memeluk agama Islam. Sehingga untuk mengikuti prosedur formal dalam perkawinan, maka sekarang ini perkawinan harus disahkan melalui KUA (Kantor Urusan Agama), kalau di masa lalu hanya dengan persetujuan dan orang tua saja sudah dirasa cukup.

3. Sanksi

Selama ini masyarakat samin tidak menerapkan sanksi yang tegas bagi anggota masyarakat yang telah melanggar norma-norma yang ada di dalam masyarakat Samin. Hal ini dikarenakan setiap warga samin mempercayai bahwa apapun kesalahan yang dilakukan oleh seseorang maka akan menghasilkan akibat yang akan dirasakan oleh orang itu sendiri. Akan tetapi seiring perkembangan jaman, maka aturan mengenai sanksi pun sudah mulai mengikuti aturan formal dalam pemerintahan desa. 
4. Teknologi

Dari sisi teknologi, kenyataan menunjukkan bahwa masyarakat Samin sudah mulai mengalami perubahan dari sisi materialnya. Hal ini ditunjukkan dengan bangunan rumah sudah seperti pada umumnya rumah masyarakat umum lainnya, di samping itu juga sebagian besar masyarakat Samin juga memiliki sepeda motor, televisi dan lain-lainnya. Demikian pula halnya dalam pertanian juga sudah banyak yang memakai teknologi.

5. Mata Pencaharian

Dahulu pertanian menjadi mata pencaharian pokok, namun sekarang ini sebagian masyarakat Samin sudah banyak yang berdagang. Walaupun sebenarnya bila ditelusuri lebih jauh, kegiatan berdagang juga melanggar norma masyarakat Samin.- Namun karena sudah semakin banyak maka hal ini pun sudah dianggap suatu kewajaran.

\section{E. Kesimpulan}

Masyarakat Samin merupakan masyarakat yang mempunyai ciri khusus yang menjadi identitas mereka dalam kehidupan sehari-hari. Identitas inilah yang terus dipertahankan dari dulu sampai sekarang. Namun seiring dengan perkembangan jaman, masyarakat Samin dengan berbagai macam keunikannya ternyata juga mengalami perubahan dari beberapa sisi. Baik dan sisi agama, mata pencaharian, perkawinan dan sebagainya. Semua perubahan yang dialami tidak terlepas dari faktorfaktor yang mempengaruhinya baik faktor internal maupun eksternal. Faktor internal lebih disebabkan oleh adanya keinginan dari masyarakat Samin sendiri. Sementara faktor eksternal lebih banyak berupa pengaruh dari luar masyarakat Samin.

Perubahan pada masyarakat Samin bisa dilihat dari aspek fisik maupun non fisik. Secara fisik, bangunan rumah masyarakat Samin sudah menyerupai rumah masyarakat lainnya. Begitu pula dengan kemajuan teknologi juga sudah banyak yang mengakses. Seperti halnya di bidang pertanian, masyarakat sudah banyak yang menggunakan mekanisasi pertanian. Sebagian masyarakat sudah ada pula yang memiliki kendaraan bermotor. Secara non fisik, ada pula beberapa perubahan yang bisa dicermati, diantaranya adalah mengenai pendidikan. Sebagian masyarakat Samin sudah ada yang mengenyam pendidikan formal, bahkan ada pula yang sudah lulus menjadi sarjana dan mengabdikan diri untuk membangun desanya. Ada pula perubahan dari sisi ketertiban administrasi sebagai penduduk, masyarakat Samin memiliki KTP yang didalamnya memuat agama mereka yaitu agama Islam. Meskipun pada prakteknya sebagian masyarakat Samin masih memegang teguh ajaran agama Adam, namun ada pula yang sudah memeluk agama Islam dan menjalankan ibadah sesuai dengan syari'at Islam.

\section{Daftar Pustaka}

Heny Prabaningrum, 1995. Saminisme (Studi Kasus di Desa Baturejo, Kecamatan Sukolilo, Kabupaten Pati, Jawa Tengah). Universitas Gadjah Mada Yogyakarta. Tidak diterbitkan.

Lexy J Moleong. 1998. Metode Penelitian Kualitatif. Cetakan ke-9. Bandung : Rosda Karya.

Rinangxu 2006. Masyarakat Samin dan Anarkisme. Tersedia pada http:/ / rinangxu.wordpress.com/2006 /12/07/samin-anarchy-rebel-budaya/. Diakses pada tanggal 4 Maret 2008.

Soerjono Soekanto. 2005. Sosiologi Suatu Pengantar. Cetakan ke38.Jakarta: PT RadjaGrafindo Persada. 
| Analisis Perubahan Sosial Pada Masyarakat Samin

Titi Mumfangati, dkk. 2007. \} irifan Lokal di Lingkungan Masyarakat Samin Kabupaten Blora Jawa Tengah

Wahono, dkk. 2002. Mempertahankan Nilai dari Gesekan Zaman di Kabupaten Kudus dan Pati, Jawa Tengah. Dalam Budi Baik Siregar dan Wahono (Ed). Kembali ke Akar : Kembali ke Konsep Otonomi Masyarakat Asli. Jakarta : FPPM.hlm 117.

Widodo, Slamet. 2008. Samin. Tersedia pada (http://learningof.slametwidodo.com/). Diakses pada tanggal 4 Maret 2008. 